IRA-International Journal of Management \& Social Sciences

ISSN 2455-2267; Vol.07, Issue 02 (2017)

Pg. no. 123-130

Institute of Research Advances

http://research-advances.org/index.php/RAJMSS

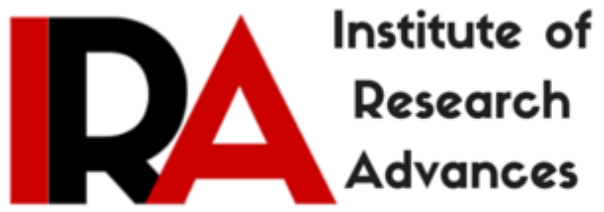

\title{
A Pragmatic Approach to CSR Evaluation: A Comprehensive Framework
}

\author{
Vaishali Rahate ${ }^{1}$, Parvin Shaikh ${ }^{2}$ \\ ${ }^{1,2}$ Datta Meghe Institute of Management Studies, Atrey Layout, Nagpur, \\ Maharashtra, India.
}

Type of Review: Peer Reviewed.

DOI: http://dx.doi.org/10.21013/jmss.v7.n2.p1

\section{How to cite this paper:}

Rahate, V., \& Shaikh, P. (2017). A Pragmatic Approach to CSR Evaluation: A Comprehensive Framework. IRA-International Journal of Management \& Social Sciences (ISSN 2455-2267), 7(2), 123-130. doi:http://dx.doi.org/10.21013/jmss.v7.n2.p1

(C) Institute of Research Advances

\section{(c)) EY-No}

This work is licensed under a Creative Commons Attribution-Non Commercial 4.0 International License subject to proper citation to the publication source of the work.

Disclaimer: The scholarly papers as reviewed and published by the Institute of Research Advances (IRA) are the views and opinions of their respective authors and are not the views or opinions of the IRA. The IRA disclaims of any harm or loss caused due to the published content to any party. 


ABSTRACT
Post Globalization Indian companies started making CSR a part of their Business strategy rather than
merely restricting it to charity or philanthropy. The most significant breakthrough in CSR took place
in 2013 with the introduction of idea of 'mandatory CSR'. With an enormous increase in the scope of
CSR, the companies are struggling to align their organizational objectives with CSR goals. The
companies are focusing on Stakeholder engagement, identifying implementation partners, capacity
building, and effective project implementation. What is amiss is impetus on monitoring and evaluation
of CSR activities. A number of CSR rating agencies have come up with their own indices, but they
lack in adequate transparency on evaluation criteria and methodology. There is also inter-agency
divergence with respect to company's evaluation and ranking. This paper proposes a comprehensive
and realistic framework which can be implemented in the Indian context for evaluating the CSR
activities.

KEYWORDS: Mandatory CSR, Monitoring \& Evaluation framework

\section{INTRODUCTION}

The EC ${ }^{1}$ defines CSR as "the responsibility of enterprises for their impacts on society". To completely meet their social responsibility, enterprises "should have in place a process to integrate social, environmental, ethical human rights and consumer concerns into their business operations and core strategy in close collaboration with their stakeholders".

The World Business Council for Sustainable Development (WBCSD) defines CSR as " the continuing commitment by business to contribute to economic development while improving the quality of life of the workforce and their families as well as of the community and society at large."

\section{GLOBAL- EXISTING CODES / STANDARDS / GUIDING PRINCIPLES ON CSR}

Universal Declaration of Human Rights:

Adopted by United Nations, this declaration paved way for many international human rights standards for all sectors entities.

\section{UN Global Compact}

An international multi-constituent, voluntary initiative based on internationally accepted ten principles in pursuit of a more sustainable inclusive global economy. The ten principles covers human rights forced labor, child labor, environmental challenges and responsibility, non discrimination, freedom of associations, collective bargaining, corruption, etc.

\section{Global Reporting Initiative (GRI)}

Since its founding in 1997, the GRI has been addressing the need for standardized approaches to corporate sustainability reporting. In 2006, GRI published Version 3.0 (G3) of its Sustainability Reporting Guidelines emphasizing performance indicators, which contain a separate section titled "Human Rights" with nine performance indicators.

\section{Organization for Economic Co-operation and Development (OECD)}

OECD guidelines contain recommendations on core labour, environmental standards, human rights, competition, taxation, science and technology combating corruption and safe guarding, consumer rights.

\section{Social Accountability 8000}

'SA 8000 ' standard for social accountability was created in 2000 by the Council on Economic Priorities Accreditation Agency (CEPAA). SA8000 developed by an international coalition of businesses, trade unions and non-governmental organizations (NGOs) on the basis of International Labour Organization (ILO) conventions - the Universal Declaration of Human Rights and the UN 
convention on the Rights of the Child. The SA8000 code of practice is broken down into nine key areas child labour, management systems, working hours, compensation, disciplinary practices, forced labour, health \& safety, freedom of association \& collective bargaining and discrimination.

\section{Principles for Responsible Investment (PRI)}

It is a set of global best practice principles for responsible investment. It provides a framework for achieving better long term investment returns and more sustainable markets.

\section{Equator Principle}

Equator principle is a set of environmental and social benchmarks for managing environmental and social issues in development project finance globally. They were developed by private sector banksled by Citigroup, ABN AMRO, Barclays and West LB and were launched in June 2003.

\section{Role of International Labour Organization (ILO)}

ILO seeks the promotion of social justice and internationally recognized human and labor rights. It formulates international labor standards in the form of conventions and recommendations setting minimum standards of basic labor rights.

\section{International Organization for Standardization (ISO) 26000}

ISO an International Standard setting body is developing a new standard on Social Responsibility namely ISO 26000 to be published in Nov., 2009. ISO 26000 is intended for use by all types of organizations and in all countries and to assist organization to operate in a socially responsible manner.

\section{Occupational Health \& Safety Advisory Services (OHSAS) Standard}

OHSAS 18001 is applicable to any organization which aims to establish a health and safety management system at work.

\section{INDIAN CONTEXT- THE COMPANIES ACT, 2013}

In India, the concept of CSR is governed by clause 135 of the Companies Act, 2013. The CSR provisions within the Act is applicable to companies with an annual turnover of 1,000 crore INR and more, or a net worth of 500 crore INR and more, or a net profit of five crore INR and more.The Act encourages companies to spend at least $2 \%$ of their average net profit in the previous three years on CSR activities. The Act lists out a set of activities eligible under CSR. Companies may implement these activities taking into account the local conditions after seeking board approval. The indicative activities which can be undertaken by a company under CSR have been specified under Schedule VII of the Act.

India has not been able to meet its MDG goals as specified by UNDP. It is also lagging behind in providing the basic amenities to its population. India has successfully reduced extreme poverty by half (47.8\% in 1990 to $20.5 \%$ in 2015), but extreme poverty targets are low and India is still a home to 300 million poor which is a bigger challenge. Moreover India ranks at the first position in the Top 10 undernourished countries in the category of developing countries of the world. Despite 86th constitutional amendment (right to education), RTE act, a larger number of students remain out of school According to the Bureau of planning, monitoring \& statistics, the dropout rates of students of Standard $1-5$ is $19.8 \%$, Std. $1-\mathrm{VIII}$ is $32.9 \%$ and Std $1-\mathrm{X}$ is $48.1 \%$.

Quality of education is also a major concern. As per the India Skills report 2015, only $37.22 \%$ of surveyed people were found employable $-34.26 \%$ among male and $37.88 \%$ among female. NSSO reports showed that only $10.1 \%$ of the labour force had received vocational training, with only $25.6 \%$ among them receiving a formal vocational training. India ranked last among 60 countries on labour productivity (World Competitiveness Yearbook, 2012). Demand for Skilled Workforce: CII (2009) had projected Incremental Human Resource Requirement till 2022 at 201 million, making the total requirement of skilled work force by 2022 at 300 million. The above figures indicate the need of 
providing skills to the youth of India which can be fulfilled if the companies work hand in hand with the government.

India also fares poorly in Gender parity. Women constitute nearly half of the countries' 1.25 billion people and gender equality - whether in politics, economics, education or health — is still a distant dream for most. This fact was driven home again sharply by the recently released United National Development Programme's Human Development Report (HDR) 2015 which ranks India at a lowly 130 out of 155 countries in the Gender Inequality Index (GII). India trails behind most Asian countries, including lesser developed Bangladesh and Pakistan which rank 111 and 121 respectively, and fares not much ahead of war-ravaged Afghanistan at 152. The GII reflects gender-based inequalities on three vital parameters: reproductive health, empowerment, and economic activity. India's record, dismal on all three counts, is especially disquieting when it comes to representation of women in Parliament. Just 12.2 per cent of parliamentary seats in the world's largest democracy are held by women as against 19.7 in Pakistan, 20 in Bangladesh and 27.6 percent in Afghanistan. Even some of the poorest nations - such as Tanzania, Zimbabwe, Rwanda, Uganda, Mozambique - are way ahead by having over a third to half of their parliament seats occupied by women. Health remains a niggling worry as well with Indian women's maternal mortality rate (MMR) being one of the world's highest. The country witnesses 190 deaths per 100,000 live births as compared to 170 pregnancy-related deaths per 100,000 births in both Bangladesh and Pakistan, states the HDR. Even in terms of the percentage of women receiving secondary education, Bangladesh at 34 per cent outsmarts India at 27 per cent. On labour force participation rate for women, as compared to Bangladesh's 57 per cent, India is at 27 per cent. The only parameter where India scores marginally better is the adolescent birth rate or the number of births per 1000 women aged 15 to 19 years. The lack of adequate sanitation and safe water has significant negative health impacts. As per the NSSO reports, only 52\% of the rural households and schools have toilets. Natural disasters affects the society everyone alike although the nature of impact varies from bad to worst. The critical and catalytic role the corporate sector can play in mainstreaming disaster management and is an inalienable part of corporate social responsibility.

In addition to Schedule VII, if the Companies focus their CSR programs on these areas, they will be contributing to capacity building, empowerment of the underprivileged, social upliftment, and inclusive growth of the nation.

\section{CSR EVALUATION}

What gets measured gets valued (as well as improved upon).

An organisation can communicate the total value of its work to internal (employees) and external (consumers, investors, suppliers, community) stakeholders; and more pertinent attention is paid to the social, environmental and economic value that the business creates. The quality of life of the community is impacted through the CSR activities. Hence, a continuous process of monitoring and evaluation system yields good results in enhancement of the socially responsible activities.CSR evaluation aims to make the program planning \& management more effective. The company can have a detail grasp of the impact of its work. While stakeholder demand for sustainability and the impact of companies' actions grows, evaluation methodologies vary a lot. There is no standard metric and there are contradictory points of view on how to capture the impact of a social action. Though there are various principles and tools available to evaluate CSR activities of a company, it is difficult to implement any tool in Indian context.

CSR Evaluation in India consists of some mandatory parameters as prescribed by Clause 135 of the Companies Act, 2013. However, for a more comprehensive evaluation, certain desirable parameters also need to be taken into account. Companies can go for a self evaluation by introspecting on the nuances of the CSR Implementation process and impact assessment. 
Fundamental components of CSR Evaluation

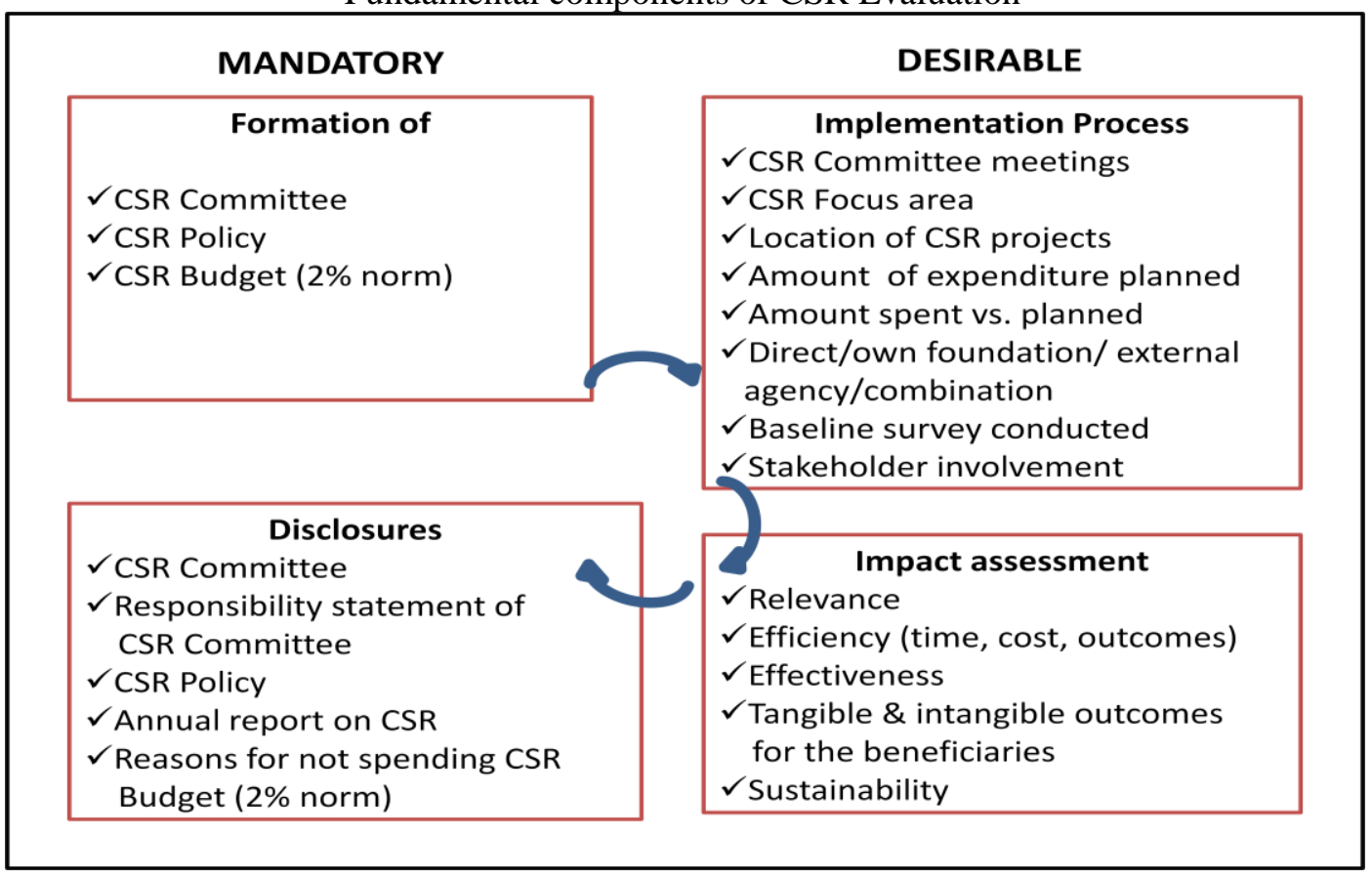

While conducting the evaluation of CSR program, enquiry has to be done whether the CSR Committee has been formed as per clause 135, whether the committee has framed the CSR policy and whether the mandatory $2 \%$ budget has been allocated for CSR. However what is more relevant is asking if the CSR Committee meetings are taking place as per the directives, what is the focus area of CSR and whether it is in alignment with the development needs of the country, what is the location of the CSR projects, amount of expenditure planned for the project, whether the project is being implemented directly, our through the companies own foundation or through some external agency or is it a combination of both, whether the focus area or CSR activities have been decided subsequent to a baseline survey in the geographical area. The level of involvement of the stakeholders gives credibility to the CSR activities.

The impact assessment should investigate the relevance of the activities conducted; examine the efficiency as regards time, cost and the outcomes. It should also study the achievement of planned outcomes; scrutinize the tangible and the intangible outcomes for the beneficiaries and the sustainability of the initiative.

Finally, we should inspect compliance of the mandatory disclosures like constitution of CSR Committee, responsibility statement of the CSR Committee, CSR policy, Annual report on CSR, and if the planned amount has not been spent then the reasons for not spending the planned budget.

We propose a framework for CSR evaluation with respect to Indian context, keeping in mind, the areas of social development of the country. It suggests the Focus areas for CSR Program, project areas, related CSR activities, the target (outcomes expected) and the evaluation criteria. Rating will be based on the points calculated.

\section{List of Focus Areas, Project areas and activities are INDICATIVE and not EXHAUSTIVE}




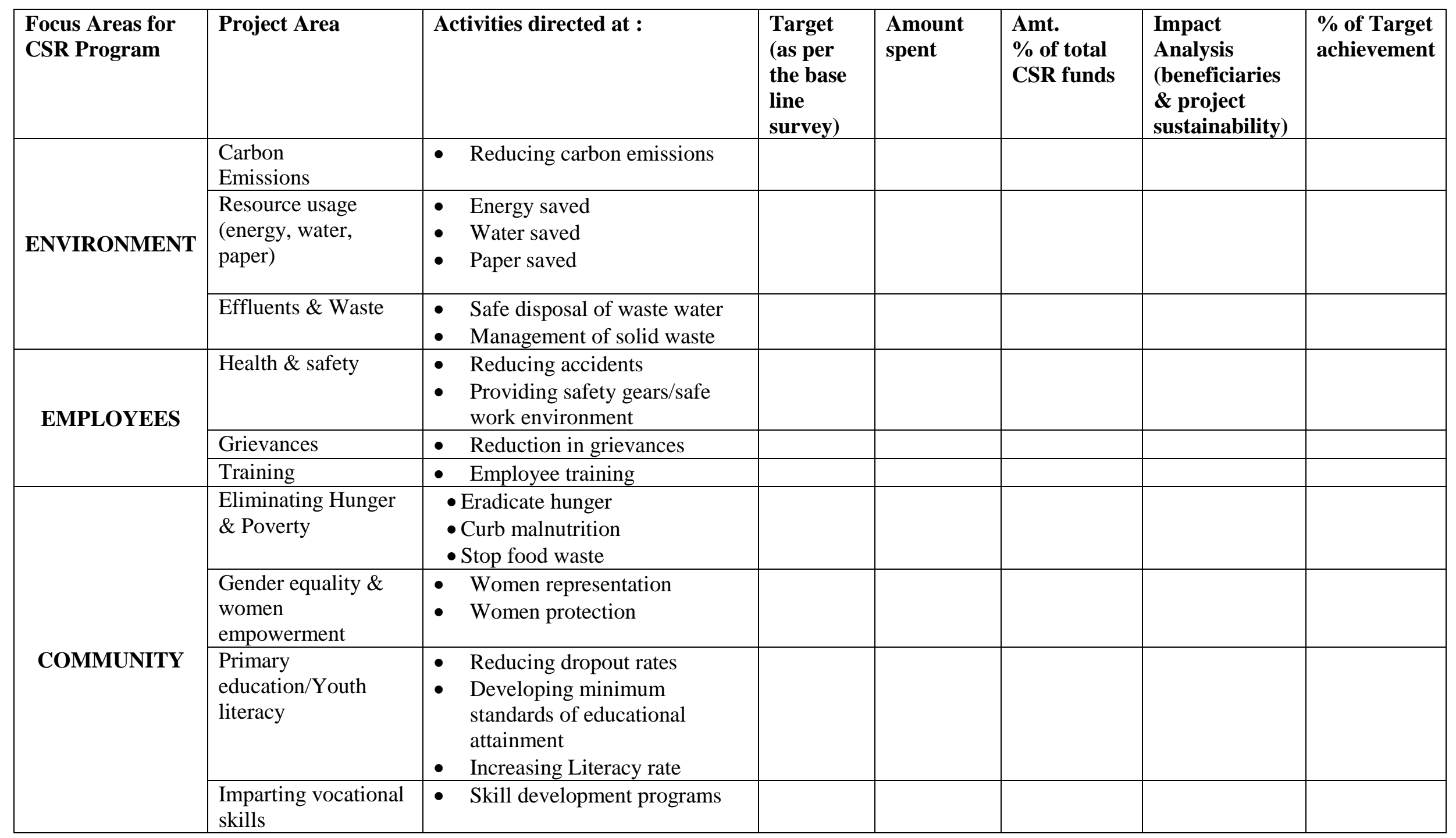


IRA-International Journal of Management \& Social Sciences

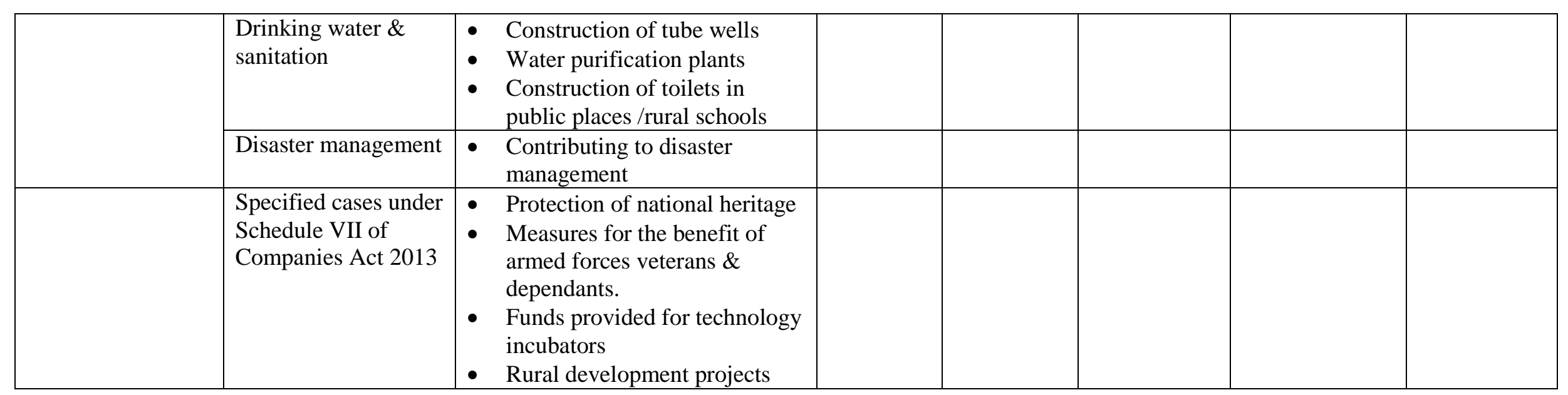


CSR Evaluation sheet

\section{CONCLUSION}

Framework for CSR evaluation needs to be simple, relevant, contextual, and convenient to use. It should include other stakeholders.

\begin{tabular}{|l|l|l|l|}
\hline Other Areas & & Target & Impact \\
\hline Suppliers & Supplier assessment & & \\
\hline Product & Right price, Right product & & \\
\hline Customer & $\begin{array}{l}\text { Customer satisfaction, Privacy, } \\
\text { Trust \&Transparency }\end{array}$ & & \\
\hline
\end{tabular}

\section{REFERENCES:}

1. http://ec.europa.eu/enterprise/policies/sustainable-business/corporate-social responsibility/index_ en.htm

2. http://www.wbcsd.org/work-program/business-role/previous-work/corporate-socialresponsibility. aspx

3. http://www.unido.org/what-we-do/trade/csr/what-is-csr.html\#ppl[g1]/0/

4. Hediger, W. 2010. 'Welfare and capital-theoretic foundations of corporate social responsibility and corporate sustainability.' The Journal of Socio-Economics 39: 518-526.

5. http://www.lbg-online.net/about-lbg.aspx 